\title{
Identification and characterization of auxiliary proteins encoded by the STLV-3 retrovirus $\mathrm{pX}$ region
}

\author{
Jocelyn Turpin 1,2,3, Theresa Nga Ling Ko ${ }^{4}$, Julien Villaudy ${ }^{1,2,3}$, Amandine Galioot ${ }^{1,2,3}$, Antoine Gessain ${ }^{4}$, \\ Louis Gazzolo ${ }^{1,2,3}$, Madeleine Duc Dodon ${ }^{1,2,3}$, Renaud Mahieux ${ }^{1,2,3^{*}}$ \\ From 15th International Conference on Human Retroviruses: HTLV and Related Viruses \\ Leuven and Gembloux, Belgium. 5-8 June 2011
}

The PTLV-3 group includes simian viruses (STLV-3) and the recently identified human viruses (HTLV-3). These viruses display a high percentage $(>95 \%)$ of sequence identity. Recent studies have shown that the auxiliary proteins of complex retroviruses such as HIV and HTLV-1 are playing an important role in the viral life cycle in vivo. However, it has not been determined yet whether the genome of the Primate T-cell Lymphotropic viruses, type 3 encodes such proteins.

To uncover the potential presence of auxiliary proteins, we first extracted RNA from cells either infected with STLV-3 or transfected with a STLV-3 infectious molecular clone. RT-PCR experiments using primers specific of the $\mathrm{pX}$ region allowed the amplification of two different doubly spliced mRNAs, one encoding a putative 63 amino-acid protein and another one encoding a putative 79 amino-acid protein. Based on the molecular weight prediction, we named these proteins $\mathrm{p} 8$ and $\mathrm{p} 9$, respectively. The $\mathrm{p} 8$ sequence is present in $90 \%$ of all HTLV-3 and STLV-3 strains. The N-Ter 21 amino acid sequence is shared with the corresponding Rex3 sequence. This sequence was found to be homologous to that of Rex1, which contains the nucleolar localization signal, and the RNA binding domain. Interestingly, after transfection of a p8 expression vector, we observed that the protein localized within the nucleolus. We are proceeding to the characterization of $\mathrm{p} 8$ subdomains as well as to the functional analyses of the $\mathrm{p} 8$ functions. These experiments will allow us to determine whether $\mathrm{p} 8$ represent the counterpart of an HTLV-1 auxiliary protein.

\section{Author details}

${ }^{1}$ Virologie Humaine, INSERM-U758, Lyon, France. ${ }^{2}$ Ecole Normale Supérieure de Lyon, Lyon, France. ${ }^{3}$ IFR 128 BioSciences Lyon-Gerland, Lyon, 69364,Cedex 07, France. ${ }^{4}$ Unité d'Epidémiologie et Physiopathologie des Virus Oncogènes, CNRS URA 3015, Institut Pasteur, Paris, 75015, France.

Published: 6 June 2011

doi:10.1186/1742-4690-8-S1-A133

Cite this article as: Turpin et al.: Identification and characterization of auxiliary proteins encoded by the STLV-3 retrovirus pX region. Retrovirology 2011 8(Suppl 1):A133.

* Correspondence: renaud.mahieux@ens-lyon.fr

${ }^{1}$ Virologie Humaine, INSERM-U758, Lyon, France

Full list of author information is available at the end of the article

Submit your next manuscript to BioMed Central and take full advantage of:

- Convenient online submission

- Thorough peer review

- No space constraints or color figure charges

- Immediate publication on acceptance

- Inclusion in PubMed, CAS, Scopus and Google Scholar

- Research which is freely available for redistribution

\section{() Biomed Central}

